
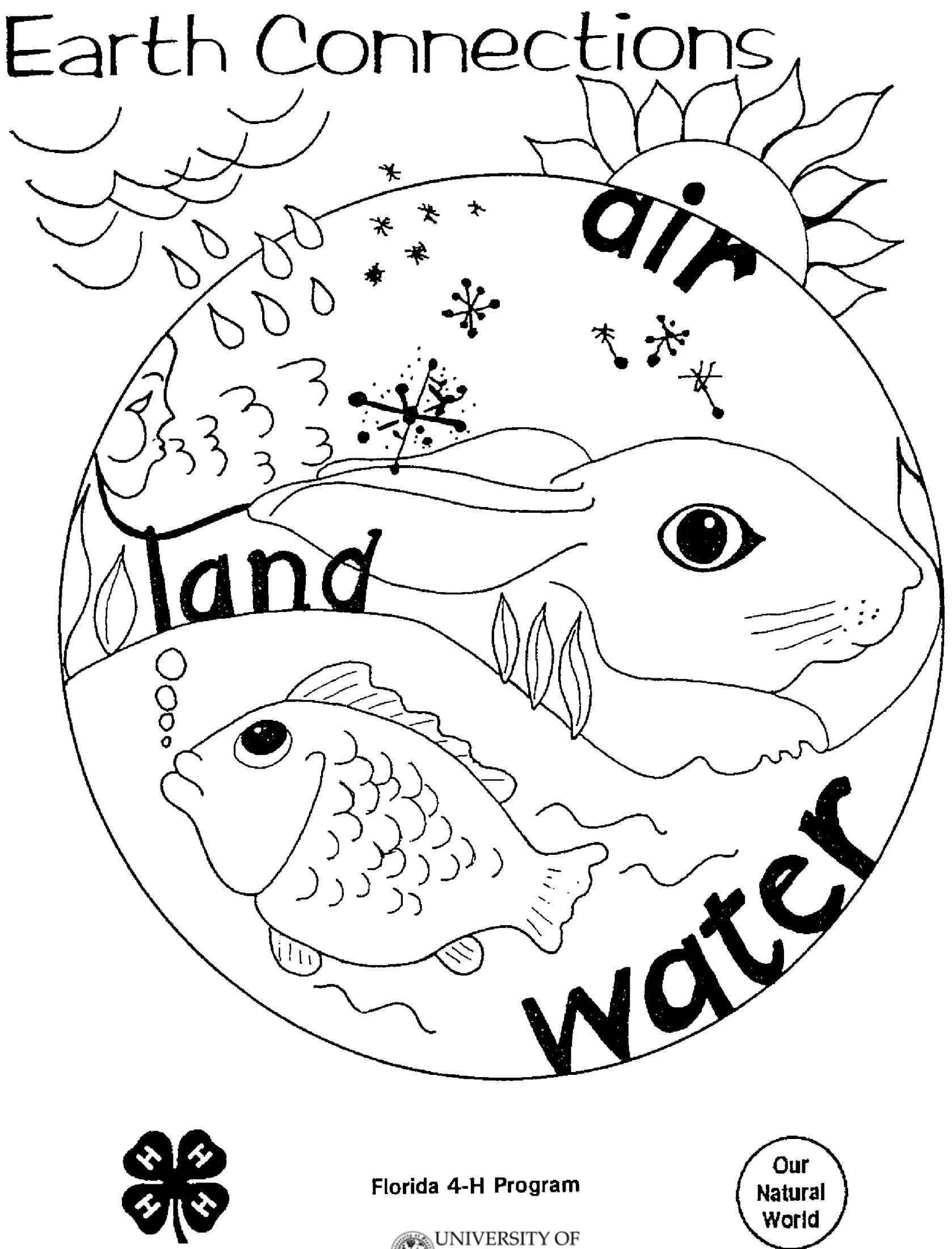

Florida 4-H Program

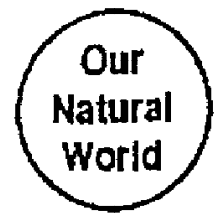




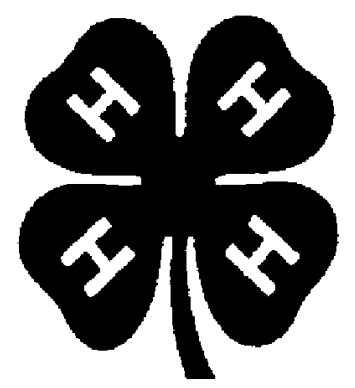

\section{Special Thanks...}

This 4-H Environmental Education Project was funded from the Save Our State Environmental Education Trust Fund Grant Program, Florida Advisory Council on Environmental Education, Tallahassee, Florida.

Appreciation and thanks are extended to the pilot sites in Alachua, Collier, Duval, Okeechobee, Orange, Sarasota, Suwannee, Broward, and DeSoto Counties for their contributions.

\section{Acknowledgements...}

Earth Connections includes an adaptation of selected activities from a variety of sources listed in the Bibliography.

The authors wish to also acknowledge the many contributions of ideas, concepts, and activities made by the Design Team Members.

4-H IS A PROGRAM OF THE UNIVERSITY OF FLORIDA COOPERATIVE EXTENSION SERVICE AND IS OPEN TO ALL INDIVIDUALS REGARDLESS OF RACE, COLOR, CREED OR NATIONAL ORIGIN. CONTACT YOUR LOCAL COUNTY COOPERATIVE EXTENSION SERVICE OFFICE FOR OTHER 4-H PROGRAMS, OR CALL THE STATE 4-H OFFICE AT THE UNIVERSITY OF FLORIDA (904) 392-1744 FOR MORE INFORMATION. 


\section{A CHAIN OF LIFE EXPERIMENT!}

What you will need:

2 jars or 2-liter soda bottles, with tops cut off

Seeds of grass, clover, beans

Sand, soil, pebbles

Water

Plastic wrap, rubber band

What you do:

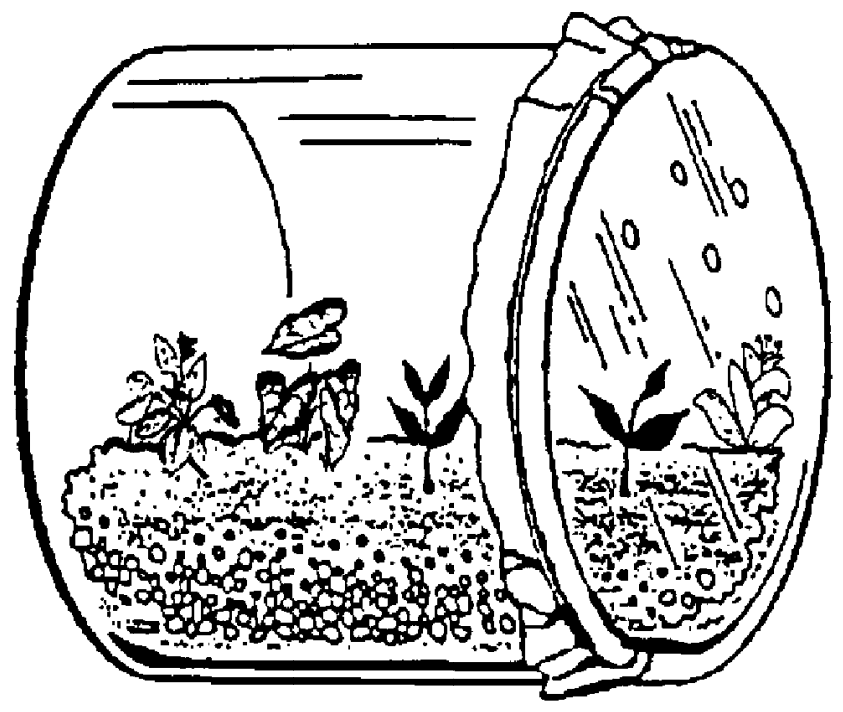

- Place a layer of pebbles in bottom of jar.

- Place a layer of soil or sand next.

- Moisten the soil with water.

- Plant the seeds.

- $\quad$ Cover the container tightly with plastic wrap.

- $\quad$ After the seeds sprout, punch holes in plastic wrap.

- $\quad$ Prepare 1 jar and put in dark place.

- $\quad$ Prepare 1 jar and put in sunny place (not direct sunlight or direct heat).

\section{What happens?}

Day 3

Day 5 


\section{COMPLETE THE PICTURE...}

Draw a picture of where large animals and plants live, and what they need.

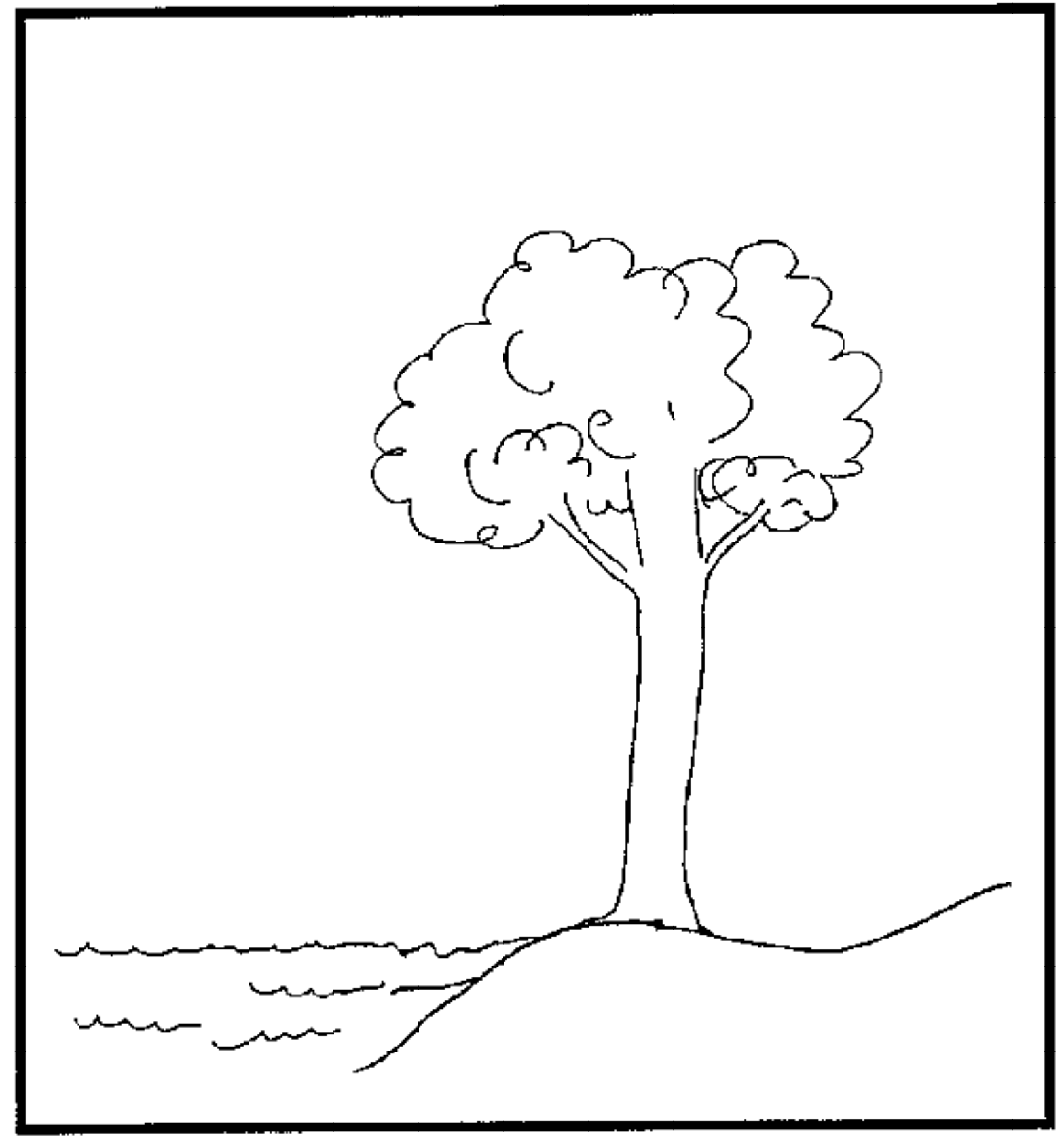

Ecosystem...is living and nonliving things within a specific area. 


\section{FIND THE ECOSYSTEMS}

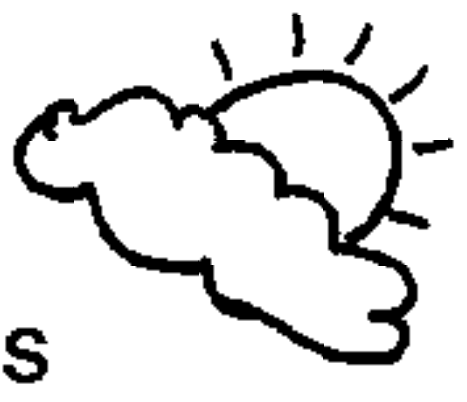

Forests

$\begin{array}{llllllllll}\text { A } & \mathbf{L} & \mathbf{O} & \mathbf{F} & \mathrm{J} & \mathrm{I} & \mathrm{B} & \mathbf{C} & \mathbf{O} & \mathbf{D}\end{array}$

Prairies

$\begin{array}{llllllllll}F & N & B & O & C & E & A & N & F & E\end{array}$

Lake

$\begin{array}{llllllllll}P & C & W & \mathbf{R} & \text { I } & T & \mathbf{T} & \mathbf{P} & \mathrm{O} & \mathrm{S}\end{array}$

River

$\begin{array}{llllllllll}L & A & K & E & B & M & M & A & W & E\end{array}$

$\begin{array}{llllllllll}D & E & S & S & T & A & Z & E & V & R\end{array}$

Swamp

$\begin{array}{llllllllll}R & P & \text { I } & \text { T } & \text { W } & \text { I } & \text { M } & \text { Q } & P & \mathbf{T}\end{array}$

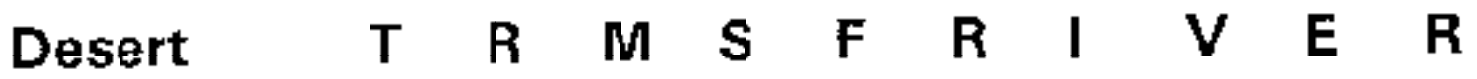

$\begin{array}{llllllllll}K & W & \mathbf{P} & \mathbf{R} & \mathbf{A} & \mathbf{I} & \mathbf{R} & \mathbf{I} & \mathbf{E} & \mathbf{S}\end{array}$

Ocean

Circle the different natural ecosystems you can find.

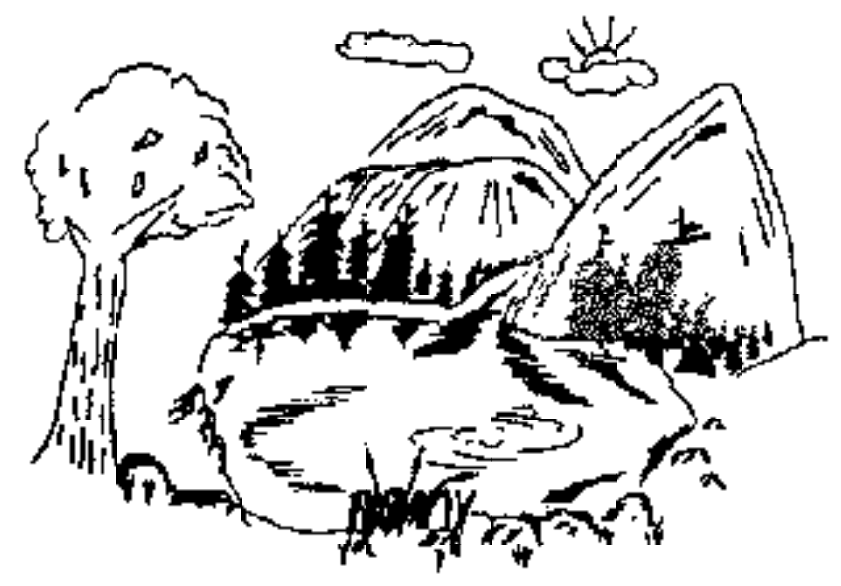


Where Ifs anhe warter?

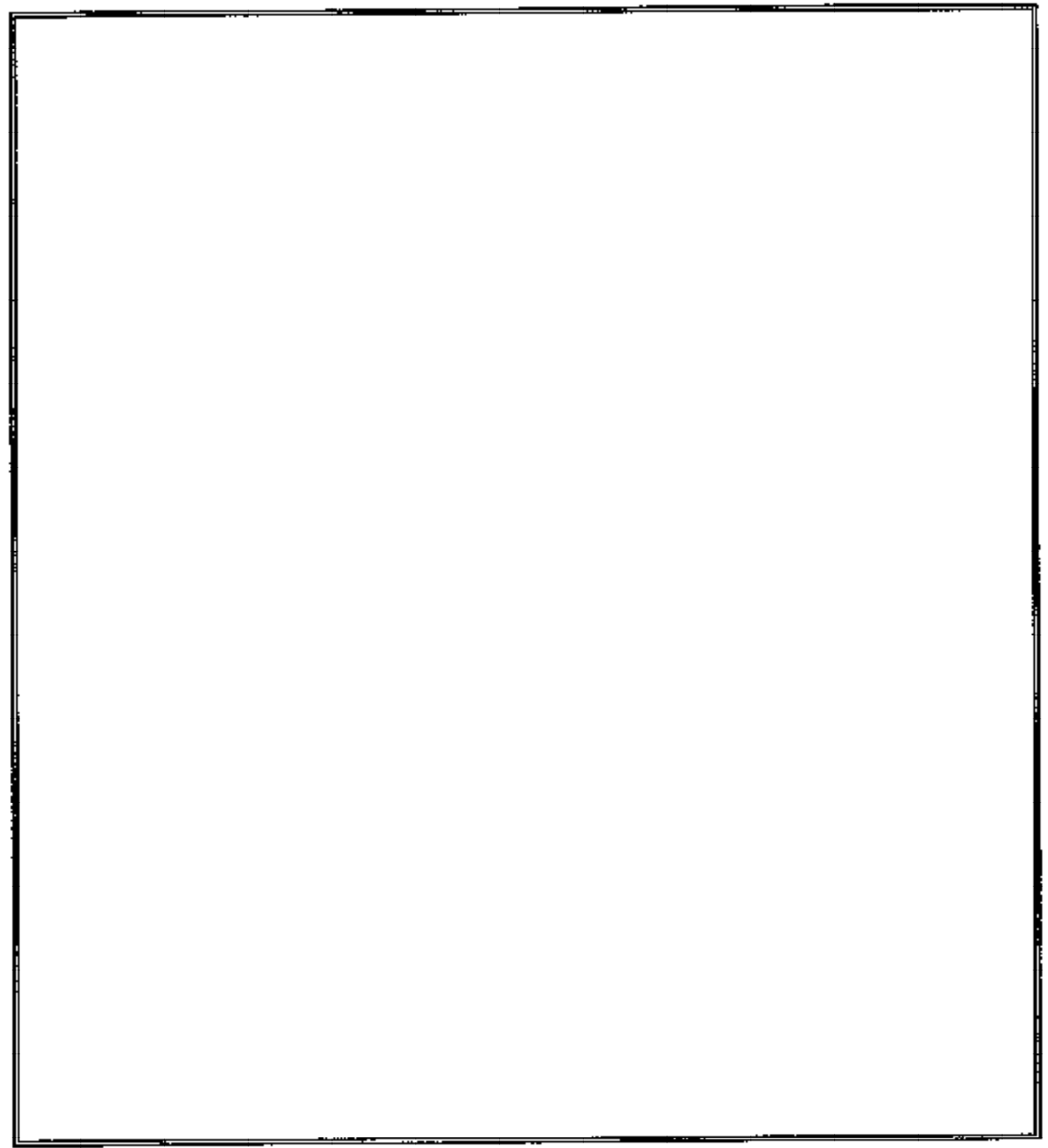

Draw a map of your town...include lakes, rivers, streams or other places you see lots of water. 


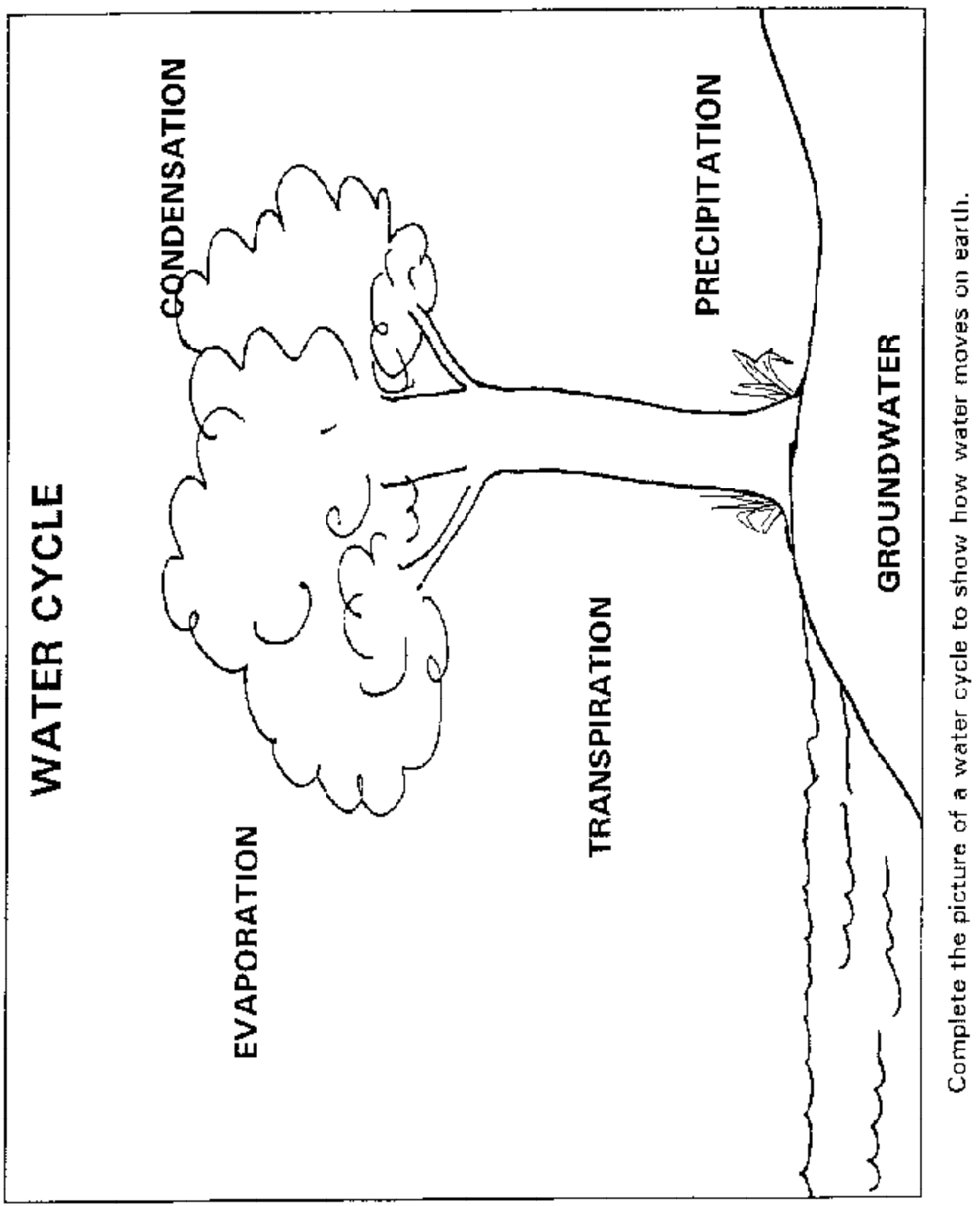




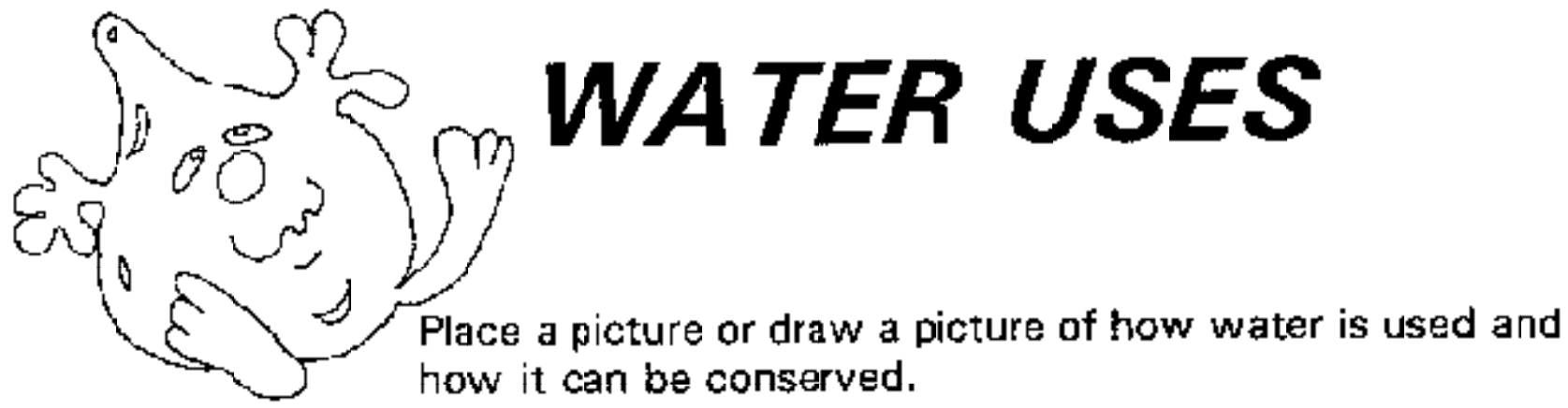

$\Leftrightarrow$ GT HOME

(3) FOR FUN and PLAY 
OFOR JOBS

$\triangle$ FOR OTHER THINGS 
COLOR THE PICTURES

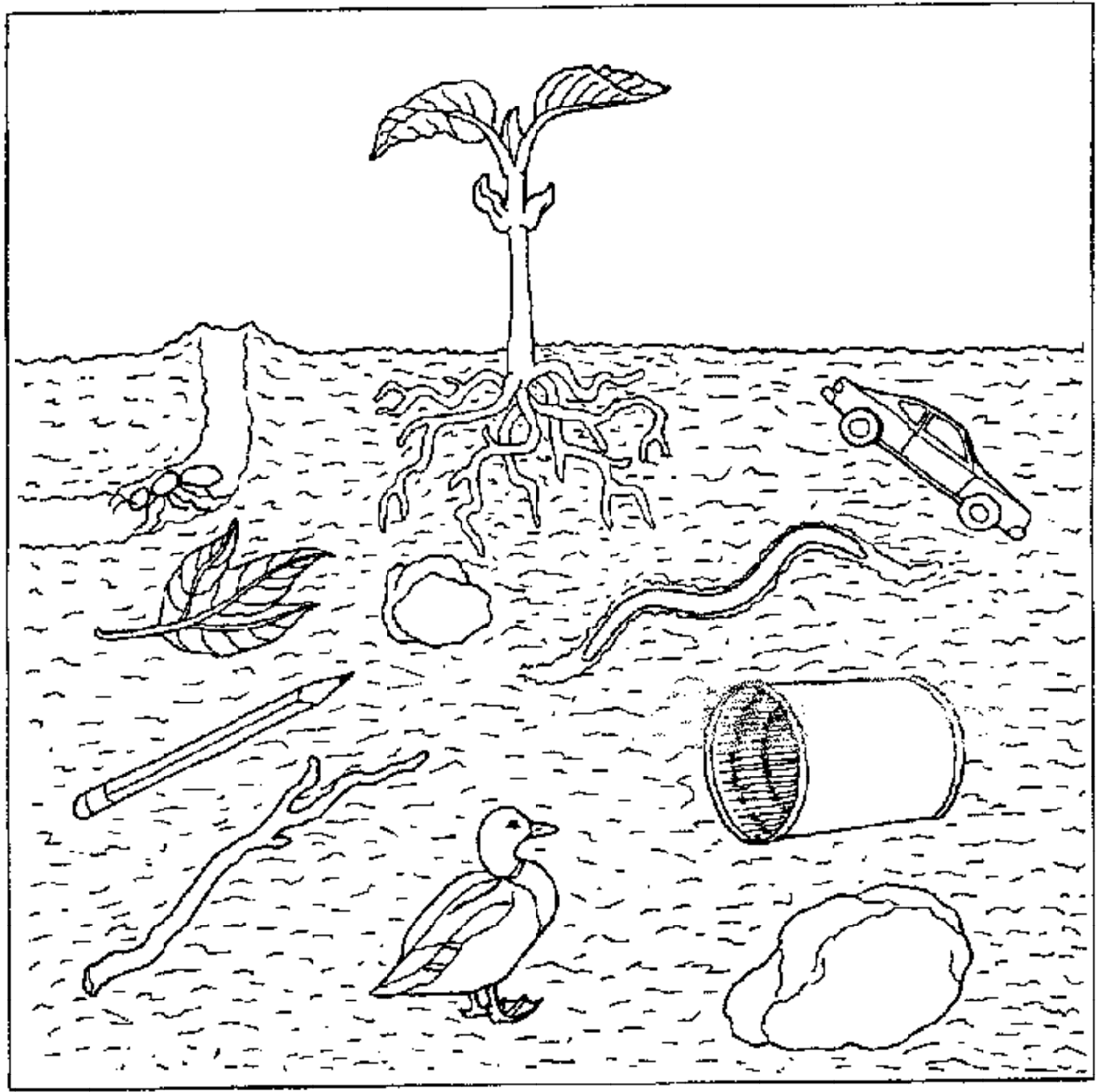

\section{Sorting Through Soil}

You Will Need:

- A small cup of soil
- Wagrifying Glass
Nowspapers or large
container to spread
your soil sample

What To Do:

- Loor at the soil.

- Circle the things in the pisture you found, that belong in the soli.

- Put an $x$ on the trings in the picture that don't belong in the soll. 


\section{Soil, Terrific Soil!}

\section{You Will Need:}

- cardboard, heavy paper

- different types of soil

- pencils

- glue

- plastic spoons

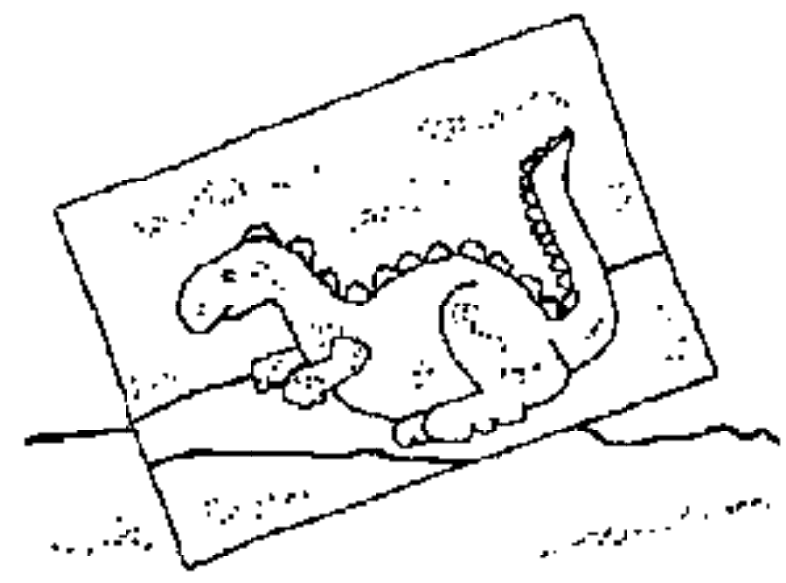

\section{What To Do:}

- Draw a picture on your paper.

- Put glue on picture parts.

- With spoons, sprinkle soil on glue.

- Wait 5 minutes, sprinkle off excess soil.

\section{WHY IS SOIL IMPORTANT TO US?}

How many ways is soil used around your home? 


\section{Let's find out how important soils are to you! Lead Sammy through the maze.}

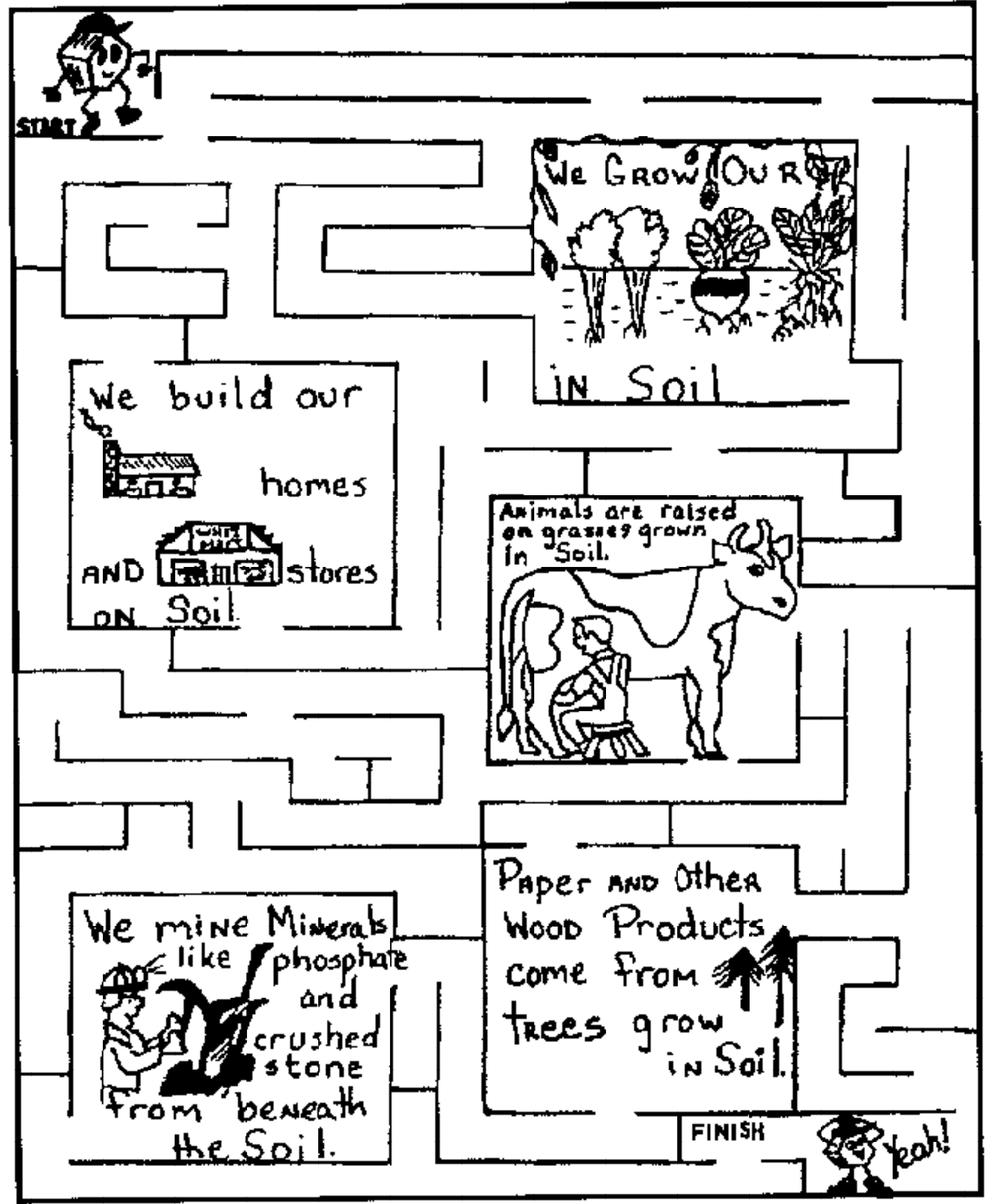




\section{BE A SOIL SCIENTIST}

Follow the instructor's directions for planting your seeds. Watch your plants for the nex. five to ten days. Maasure the plants each day.

Write down the height of the plant on the chart.

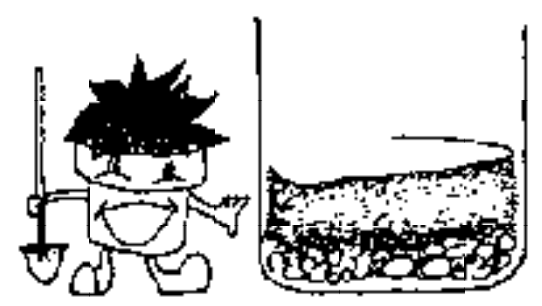

\begin{tabular}{|c|c|c|c|}
\hline Day & $\begin{array}{l}\text { Plant Height in } \\
\text { Sandy Soil }\end{array}$ & $\begin{array}{l}\text { Plant Height in } \\
\text { Potting Soil }\end{array}$ & $\begin{array}{l}\text { Plant Height in } \\
\text { Clay Soil }\end{array}$ \\
\hline 1 & & & \\
\hline 2 & & & \\
\hline 3 & & & \\
\hline 4 & & & \\
\hline 5 & & & \\
\hline$E$ & & & \\
\hline 7 & & & \\
\hline$g$ & & & \\
\hline 9 & & & \\
\hline 10 & & & \\
\hline
\end{tabular}

After fve to ten davs, draw a sicture on another piece of paper of how each plant looks.

Which soil grew the tallest plant?

Which soil grew the shortest jlant?

Which soil seems to be the worst to grow these plantsin? 


\section{BUBBLING BEANS}

You will need;

20 dried beans

Glass

Water

Instructions:

Here is a simple experiment you can perform in just a few minutes.

1. Drop 20 dried beans into a clear glass. Pour warm water into the glass until the seeds are covered.

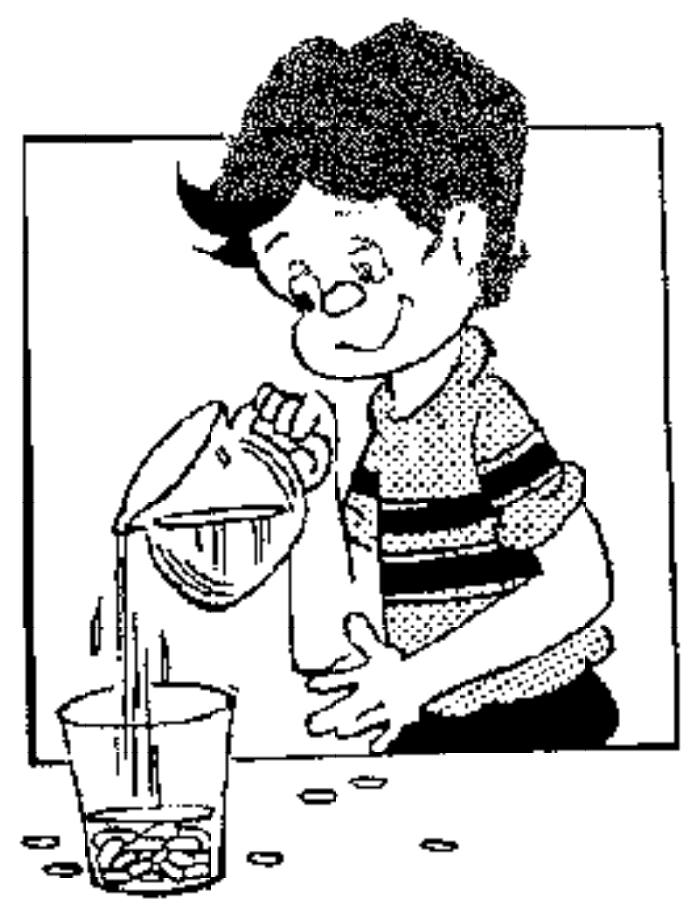

2. In a few minutes, you will see small bubbles rising from the beans. The bubbles come from the same spot on each seed. Can you explain what is going on?

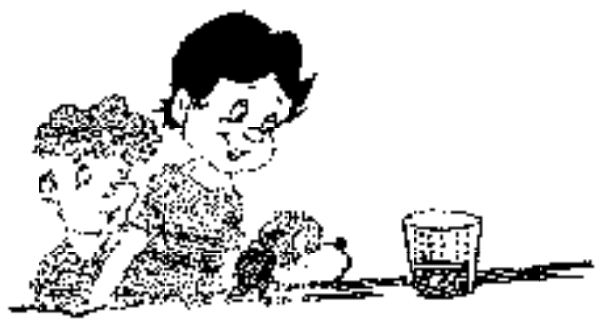

What happened?

Why? 

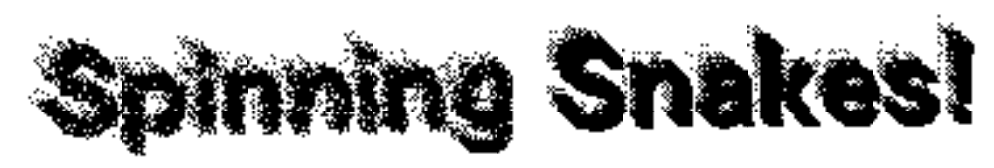

\section{What you will need:}

- 1 sheet of paper

- pencil

- scissors

- 12 inch piece of string

- tape

- heat source (radiator, hot plate, light bulb er candle)

HELP OF A PARENT!

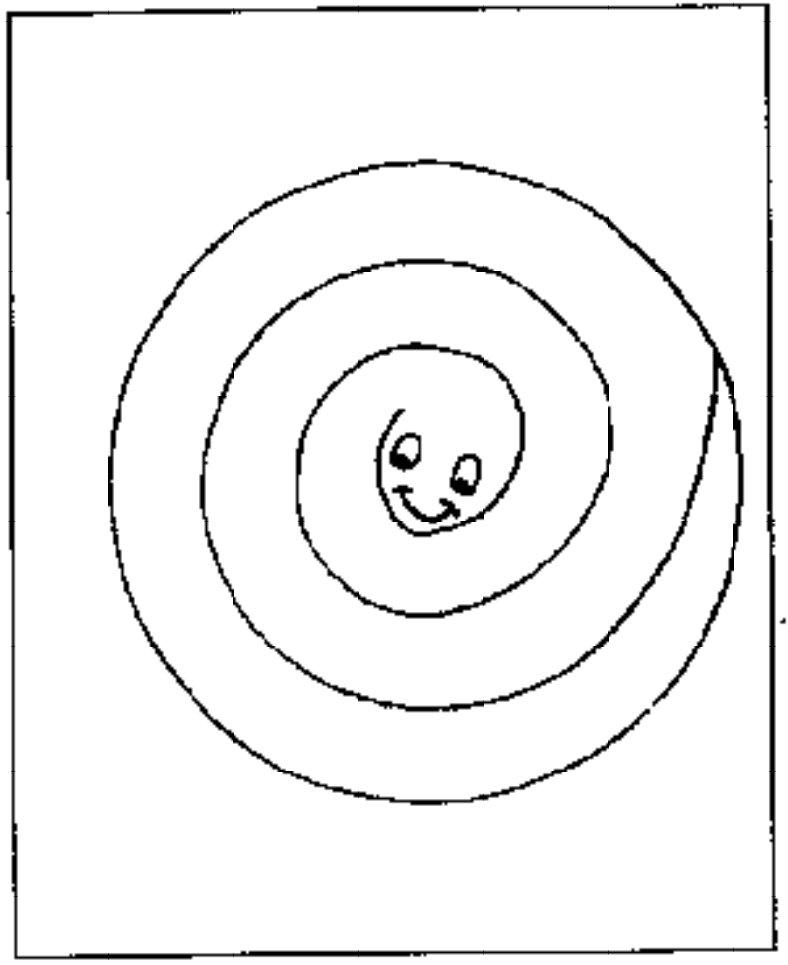

What you do:

Draw a spinning snake onto paper.

Cut picture to form a spiral snake.

Tape the string to the tail of the snake.

Hold the snake over (about 1 foot) the heat source.

The snake will spin merrily.

What happened?

Why? Because heat rising makes the air move. 


\section{PARTICLE CATCHERS!}

What you will need:

- Petroleum jelly

- 2 pieces of white paper

Look what's in the air you breathe!

or cardboard

- Magnifying glass (optional)

What you do:

- Smear petroleum jelly on your paper

- Place 1 inside the house and 1 outside

- Leave it there for several days (Bring it inside if it rains!)

- Examine your catch.
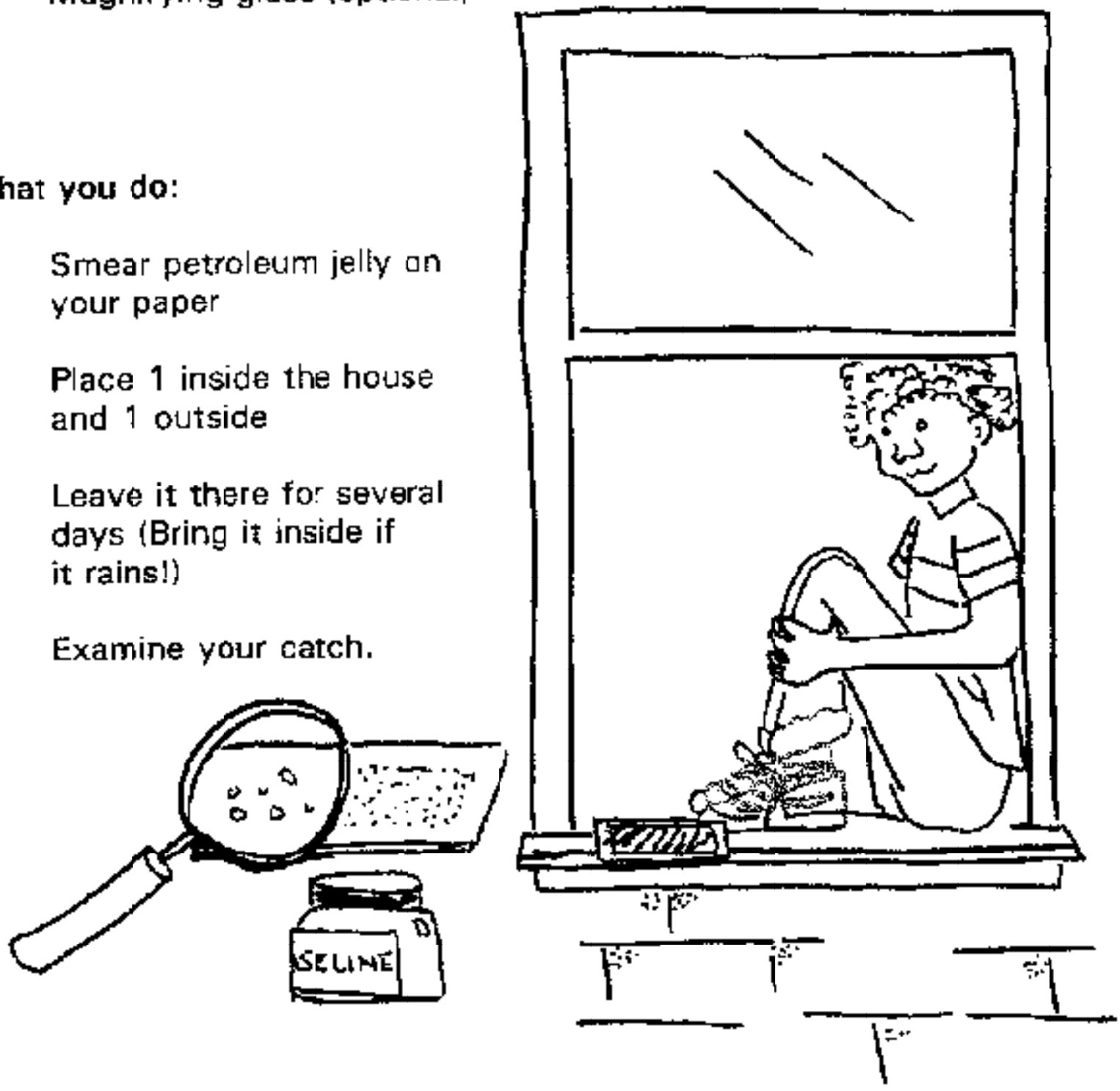


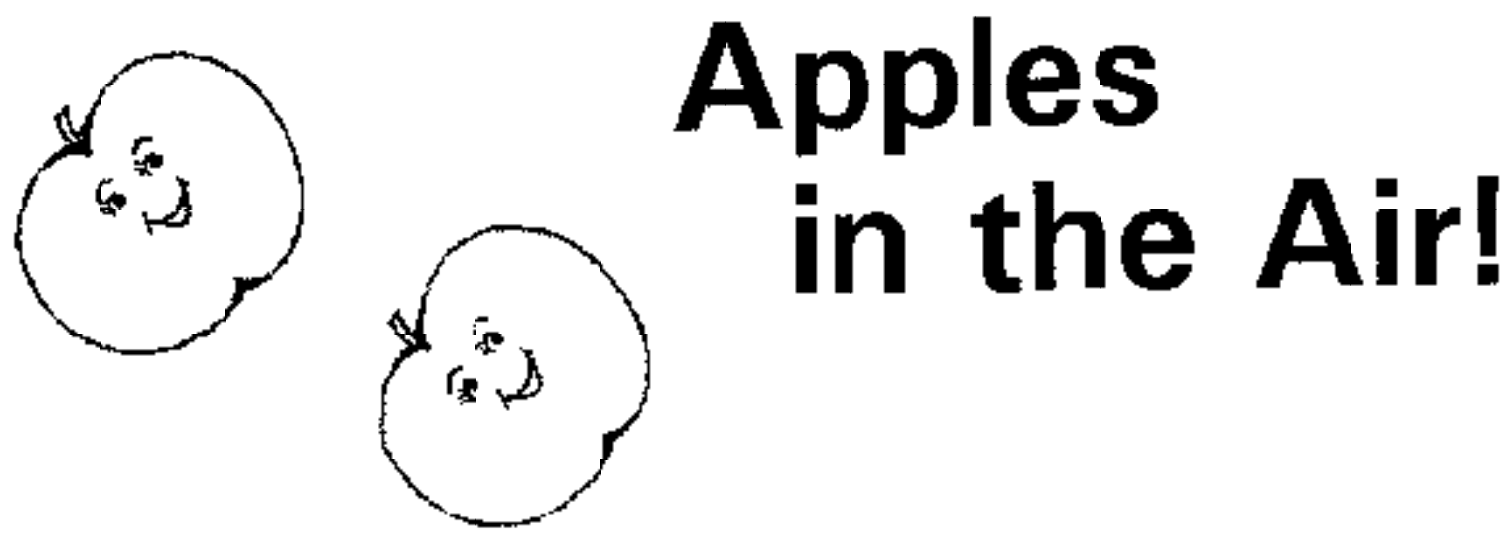

Change in apples with and without air

\begin{tabular}{|c|c|c|}
\hline DAY & PLAIN APPLE & WAXED APPLE \\
\hline 1 & & \\
\hline 2 & & \\
\hline 3 & & \\
\hline 4 & & \\
\hline 5 & & \\
\hline
\end{tabular}

Which apple spoiled the fastest?

Why did it spoil the fastest?

Why is decay important?. Because it is needed for cecycling of nutrients in soil. 


\section{HARMFUL HURTS!}

You will need:

- 2 small paper cups

- Saucer

- Sharp pencil

- Soil

- Food coloring

- Water

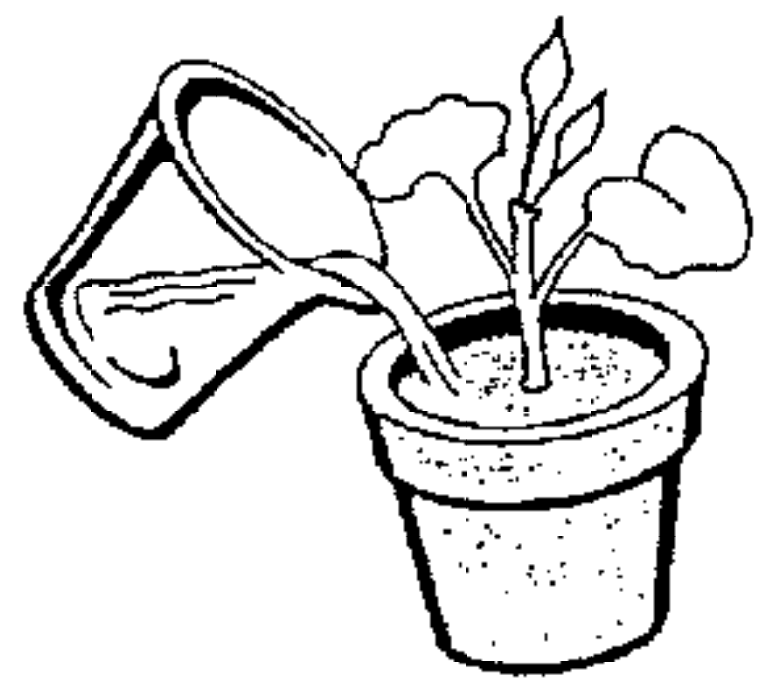

What you do:

- Punch $3-4$ holes in one cup with pencil.

- Put about 1 inch of soil in the cup.

- Place cup with soil on salucer.

- Put 2 drops of food coloring into second cup. Add 1 inch of water.

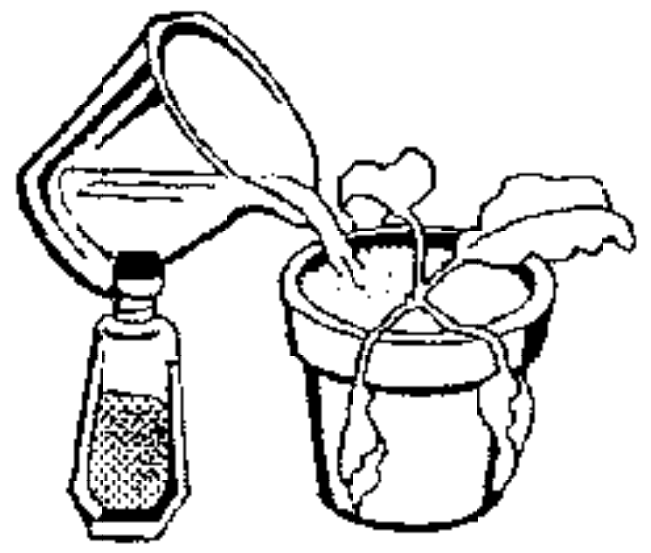

- Pour colored water into soil.

What happened?

If the food coloring was a chemical, where would it go? 


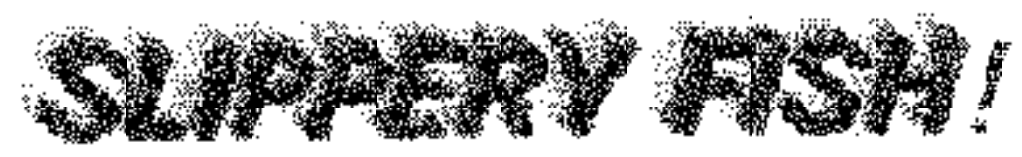

You will need:

- Newspapers

- Pan of water llarge enought to put your hand into it)

- 1/2 cup of cooking oil

- Paper towels

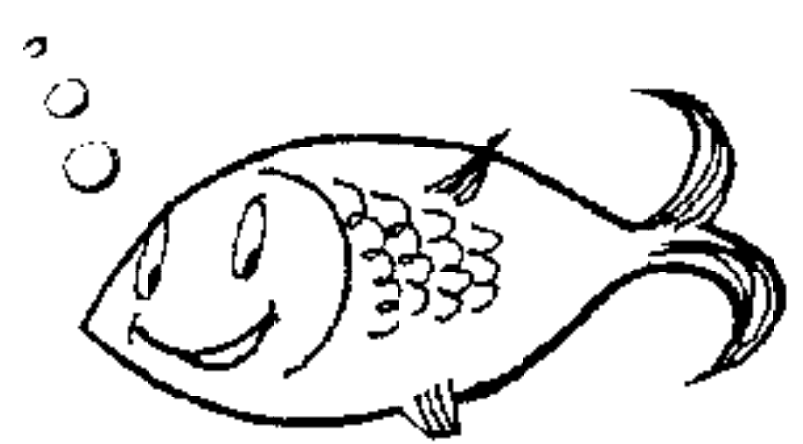

- Soap

What you do:

- Spread newspapers under pan of water.

- Pretend your hand is a fish.

- Carefuily put you hand into the pan.

- Think of how the fish, your hand--feels.

- Take your hand out. How does it feel?

- Wash your hand with soap and water.

- Clean up your "ocean lab".

How do you think fish and other animals feel when we have oil spills in the ocean?

What can happen to them? 


\section{WATER SCRUBBER}

You will need:

- $1 / 2$ gallon plastic jug

- Scissors

- Naił

- Hammer
What you do:

- Cut off the bottom of a 1/2 gallon plastic jug. Then, unscrew the cap and ask one of your parents to punch a tew small holes in it with the tip of a nail and a hammer. Screw the cap back on and turn the jug upside down.

- Fili the jug with equal layers of pebbles, gravel, coarse sand, and fine sand. The pebbles go in first, the gravel next, then the coarse sand, and, finally, the fine sand on top. Don't fill the jug completely; leave a couple of inches free.

- Hold the jug over a clear glass jar so that it rests securely.
Pebbles, gravel, and sand (coarse and fing)

Glass jar

Muddy water

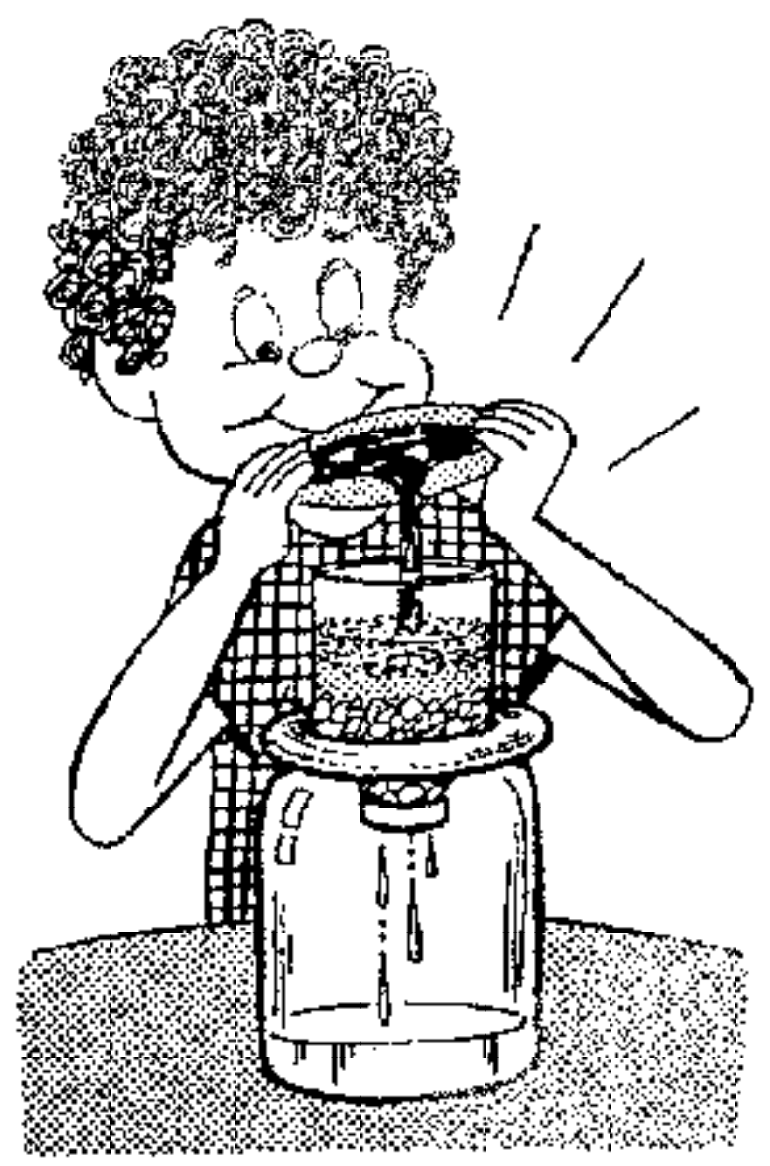

- Now, pour some muddy water onto the sand. In a few minutes, clean water will trickle into the jar.

This is what happens:

You have just performed fitration. Filtration is the removal of material that is suspended in a liquid. The muddy water contained many impurities, and these were trapped--filtered--by the layers in your jug. The water itself, however, was free to pass through the layers and into the jar. Of course, you shouldn't drink this water because it is not really clean enough for drinking- 


\section{Our World... .earth connections!}

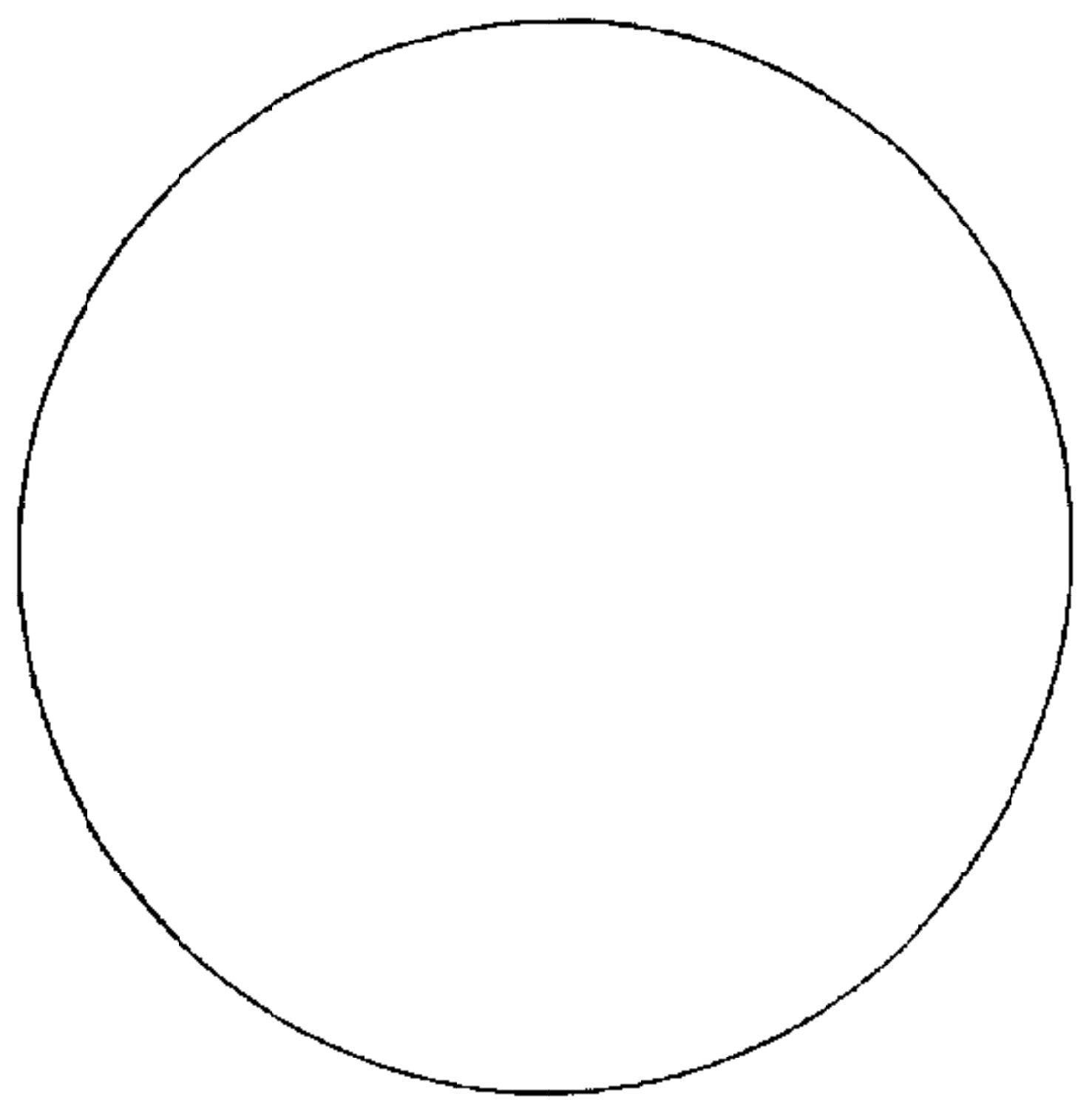

Draw a picture of one thing you can do to protect our earth's water, soil and air. 


\section{Our Natural World...}

\section{What you need:}
- crayons or markers
- paper
- tape

- scissors

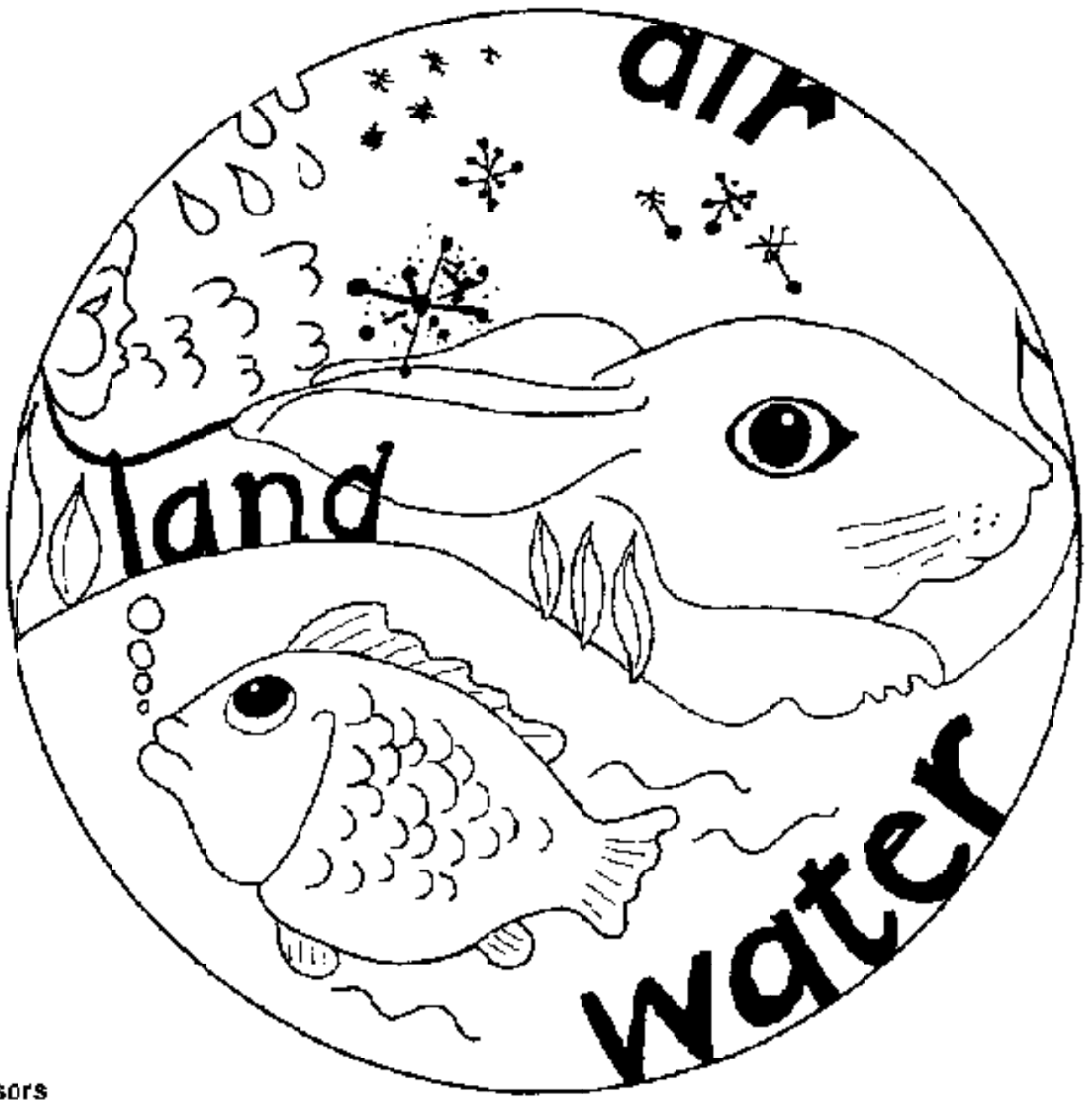

- wire coat-hanger

- yarn of various lengths

\section{What you do:}

Color the picture and cut out. Tape yan to world pictura and then tie to hanger. Draw, color and cut out gtars, moon and sun and atrach to your hanger for a color ful mobile. Hang it in a place to remind you to take care of OUR WORLD! 


\section{BIBLIOGRAPHY OF RESOURCES}

Earth Trek... Exploing Your Environment, April, 1987, Environmental Protection Agency, Washington. D.C.: Office of Public Affairs OPA87-004.

Medlieott, J. (1989) Soll and Water in North Carolina: Activity Book for 4-H'er and Family, Raleigh, N.C.: The North Carolina Agricultural Extension Service.

Gardner, K. and W.L. Hankel, Groundwater. Fargo, ND: NDSU Extension Service, North Dakota State University.

Hankel, W. L. Water is /mportant. Fargo, ND: NDSU Extension Service, North Dakota State University.

Jahnson, S.O., EDE 3804 Science Lecture Notes, University of Florida.

Sevebeck, K.P., Burch, S.K. and Pettus, A. M. Be Wafgr-Wise. (1983), Blacksburg. VA: Virginia Resources Research Center, Virginia Tech.

Walter, H.W., 4-H Nature Detectives, Member Manual. (1987). Government of Newfoundland and Labrador, Department of Culture, Recreation and Youth, Youth Services Division. 
Name

Address

Name of Club/School

Leader/Teacher's Name

\author{
4-H Club Motto \\ "To make the best better"
}

\section{4-H Pledge}

\section{f Pledge:}

My head to clearer thinking

My heart to greater loyalty

My hands to larger service, and

My health to better living

for my club, my country, and my world.

\section{4-H Colors \\ Green and White}

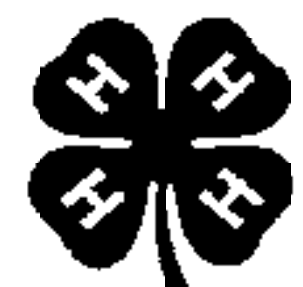

Earth Connections has been preparad using furds from the Save Our Stete Enwirpnmental Education Trust Fund Grant Program and is the sole property of the Stete of Florida. Information cancerning the usa, display or reproduction of this materiai may be obtained by contacting: Forida Advisory Council on Environnemiat Ertucation, Roort 237 folland Building. Tallahassee. Florida 32399-2400 Telephant: 19041 407-0123

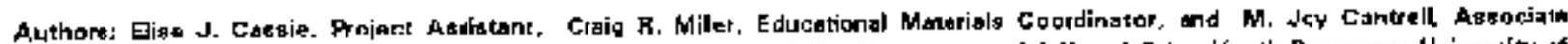

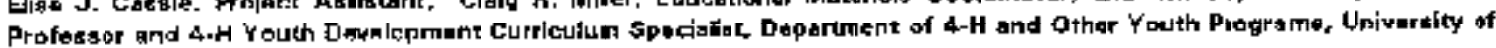

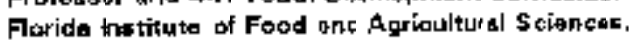

Gover Dotign: Kanneth R. Cogsin

Word Pracessing

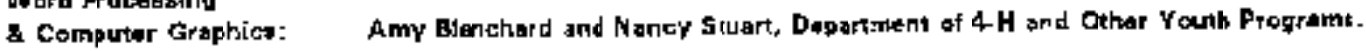

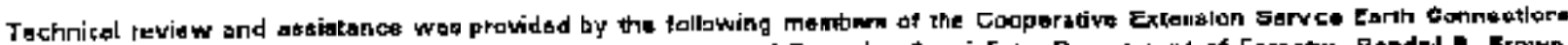

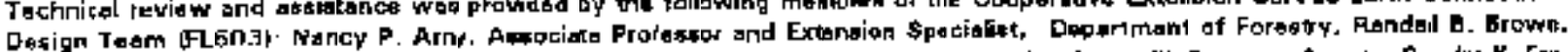

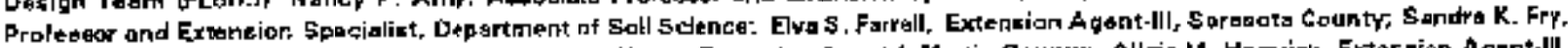

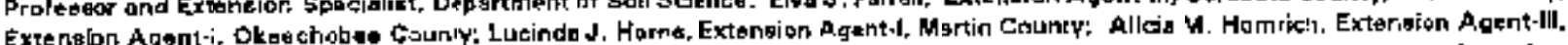

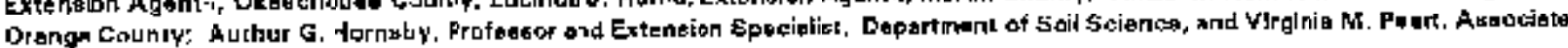

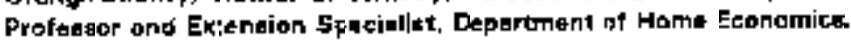


1. This document is 4HESM11 of the Florida 4-H Youth Development Program, Florida Cooperative Extension Service, Institute of Food and Agricultural Sciences, University of Florida.

Reviewed June 2002. Please visit the EDIS website at http://edis.ifas.ufl.edu.

2. Elise J. Cassie, Project Assistant, Craid R. Miller, Educational Materials Coordinator, and Joy Jordan, Ph.D., associate professor/ 4-H Youth Development Specialist, Department of Family, Youth and Community Sciences, Cooperative Extension Service, Institute of Food and Agricultural Sciences, University of Florida, Gainesville 32611.

COOPERATIVE EXTENSION SERVICE, UNIVERSITY OF FLORIDA, INSTITUTE OF FOOD AND AGRICULTURAL SCIENCES, Christine Taylor Waddill, Director, in cooperation with the United States Department of Agriculture, publishes this information to further the purpose of the May 8 and June 30, 1914 Acts of Congress; and is authorized to provide research, educational information and other services only to individuals and institutions that function without regard to race, color, age, sex, handicap or national origin. The information in this publication is available in alternate formats. Single copies of extension publications (excluding 4- $\mathrm{H}$ and youth publications) are available free to Florida residents from county extension offices. Information on copies for out-of-state purchase is available from Publications Distribution Center, University of Florida, PO Box 110011, Gainesville, FL 32611-0011. 